For citing: Fatić A. Value identities: Personality as an ecology of values // Socium i vlast. 2021. № 2 (88). P. 18-25. DOI 10.22394/1996-0522-2021-2-18-25.

DOI 10.22394/1996-0522-2021-2-18-25

UDC $17.03+177.1$

\section{VALUE IDENTITIES: PERSONALITY AS AN ECOLOGY OF VALUES}

Aleksandar Fatić,

PhD, Full Professor, Institute for Philosophy and Social Theory, University of Belgrade (Serbia). 45 Kraljice Natalije Street, 11000 Belgrade, Serbia.

E-mail: fatic@instifdf.bg.ac.rs

Abstract

The paper examines the concept of individual and collective value identities based an emotionalist understanding of values. The main perspective it discusses is one where emotions are the most important practical instruments for the clarification of individual and collective values. The argument implies that moral emotions are not irrational, but

have a logic of their own which can reliably pinpoint the persons' value system; emotions are thus crucial building blocks of an ethics which is able to enhance personal and moral identity. This particu-

lar ecology of moral emotions is pivotal in crisis periods, such as the global pandemics, wars or system crashes, either economic, or political, security, diplomatic or cultural. In the current circumstances, where the already shaken individual and collective values throughout the world have been shaken by the Covid 19 pandemic, understanding identities as fundamentally couched in moral emotions may be critical to saving our cultures and our legacies of social and moral capital.

Keywords: values, identities,

moral emotions, empathy, social/moral capital.

\section{The value-clarifying role of moral emotions}

The many problems and hurdles we encounter with our moral projections, evaluations and intentions, as well as with responding to morally controversial actions by others, reflect the irreducible emotional character of moral values. At least as much as we need to (cognitively) understand what these values are, we depend on our emotional reactions to values to move us to act passionately and decisively in one or another moral direction. This is what psychology sees as the 'dynamic' role of emotions, and takes it as the building block of various theoretical interpretations of how exactly emotions achieve this dynamic function [10]. As in aesthetic values, the strength and often 'existential meaning' of moral values lie largely in their appeal and ability to move us in certain directions. While in aesthetic perception there may be little room for a rational explanation of why something is perceived as beautiful or ugly, sublime or profane, in moral judgments the emotional appeal of certain values and the emotional reactions to offensive behavior largely dictate the social definition of what is morally acceptable and what is not.

There is, however, philosophically much more to the role of moral emotions than their psychologically recognized dynamic function. They also play an important cognitive role with regard to recognizing the value system of a person, group or entire society.

However rationally convincing a moral argument might be it will only be able to elicit emotions if the values which it evokes are sufficiently important to us. The more important the values, the stronger the emotional reaction will be. Thus, rather than being merely the dynamic or motivational side to acting morally based on rational arguments, moral emotions are also unique cognitive windows of insight into which actual moral values are the most important to us. Often the moral debate (and sometimes also policy debate) in democratic societies revolves entirely around the emotional capture and articulation of values rather than any rational argument. Perhaps the best and currently most striking example is the painful debate over issues such as the respect of difference versus freedom of expression, which has taken place in Europe after the January 2015 terror attacks in Paris over the satirical caricaturing of Prophet Mohammad by a French cartoon magazine (which has since continued with culturally offensive illustrations being published) [4]. The rationally mutually compatible claims of inter-cultural respect on 
the one hand, and reasonable freedom of expression, on the other, have clashed in this case to the point of potentially marking the beginning of an entirely Huntingtonean clash of cultures, which Umberto Ecco has poignantly described by saying that 'we are in a war up to our necks' [6].

This particular example shows the emotional side of moral values which can easily be characterized as 'irrational': the abuse of freedom of speech to hurl cultural insults at others by the Charlie Hebdo magazine to start with, a violent, criminal response by those offended which followed (the terror attack on the magazine in January 2015 and the killing of its staff members). The outcome appeared particularly discouraging, with, an escalation of the insulting action by the French society by the spiteful printing of a five-fold run of copies of the same caricaturing cartoons of Prophet Mohammad, in order to affirm the editorial liberties in France [12].

The philosophical point of this example, however, does not necessarily hinge on the apparent irrationality of the culture conflict; it is rather in the clear illustration that the tragic event in Paris is of just how crucial moral emotions are both for understanding the importance and role of particular values to particular people (or groups, or cultures), and for moving them to act, even to the point of self-destruction, in the defence of those values. The structure of the emotional articulation and response to values is the same in the case of moral and aesthetic values: the emotions reliably identify the most important values, whether they are in the realm of reverence or the sublime, moral authority or beauty. However, the strength of the emotions tends to be much greater when moral values (and these unavoidably include religious ones, as well) are at stake. Thus, the relevance of moral emotions can hardly be overemphasized in discussions of practical moral issues such as virtue, tolerance, or respect.

One relatively obvious practical role of moral norms (and the corresponding moral values) is that they restrict spontaneity: where one might spontaneously act selfishly, moral norms require one to show a degree of fellow-feeling and consideration; where one would rather flee the danger, moral norms require them to fight for the right cause (usually corresponding to a general interest). Where one would exercise one's liberties (including the right to free speech) so as to insult others, moral values restrict the intrusion on the integrity and well-being of others. Equally, where one would exercise violence on the weaker or helpless, moral normativity is there to stop them. In this, most conservative of its roles (which is, of course, not its only role or form), ethics is a sort of fence that keeps us on the rights side of things. In its restrictive function ethics rests on rational moral judgment which, ideally, can control emotions when they would otherwise lead the person to act immorally.

There is, however, a complementary role for ethics, which rests firmly on the person's (or group's) ability to exercise a moral spontaneity which is motivated and fueled by moral emotions, and which goes against any type of rational judgment. Actions of self-sacrifice powerfully illustrate this aspect of ethics which crucially, and in many cases exclusively, depends on the emotional spontaneity of one's moral personality. The person who dives in a foaming sea to rescue a shipwreck victim acts outside any immediate framework of rational moral judgment or calculations of the 'pros' and 'cons' of the action.

In fact, when one considers the active making of sacrifices, one often finds that the less calculated and more immediate the sacrifice, the more practical moral approval it tends to earn. There is something of an implicit expectation that sacrifices should be made 'full-heartedly', without calculation, in order to merit a positive evaluation of character. In acting selflessly, the less rational consideration and more 'automaticity' or spontaneity there is, the more virtuous the actor will tend to be considered. This tendency is reflected in the common phrases 'giving oneself for others unthinkingly', or 'acting immediately/without a moment's hesitation'. In fact, most people would agree that there is something more 'heroic' about a person who jumps in the water to assist a drowning victim 'unthinkingly' than about another person who stops, ponders what to do, and then jumps to do the same. The reason we tend to consider the former more virtuous than the latter is that we assume that the former possesses a virtuous emotional spontaneity, whereas the latter appears to act morally desirably by imposing rational moral judgment on one's emotional spontaneity, where the spontaneity itself is not virtuous. In other words, it appears that we tend to value virtuous spontaneity (or the free exercise of positive moral emotions, such as empathy or a sense of solidarity) more than rational moral judgment by itself.

The same ambivalent role of emotions permeates the moral discourse on justice. Much of the legal regulation of the right to use violence in self-defence, for example, is built on the assumption that emotions can play a variety of roles in such situations. On the one hand, one's 
'fear for one's life', if it can be established sufficiently credibly, justifies, in many jurisdictions, one's taking measures in self-defence which might result in the assailant's death. Where the evidence of such fear is lacking, the legal consequences of the same type of self-defence typically involve a serious prison sentence [7]. On the other hand, the same jurisdictions regulate the limits to justified self-defence on very rationalistic, even entirely unrealistic grounds. Often one is considered justified in applying force on the assailant only up to the point when an opportunity for escape emerges, and only if the threat is to one's person or the life or limb of another. This means that, for example, if one scratches your car deliberately in front of you, you are not legally justified to confront and detain them with any degree of physicality. While such regulation may seem very nice and civilized, it flies in the face of most people's spontaneous reactions of outrage and anger when someone damages their property deliberately in front of them [7, p. 150-175]. In fact, such regulations arise from a fear of what emotions might do, or the extent to which they may lead the person in reacting; thus, the impulse of the regulators is to extinguish any legitimate role for anger in all non-essential situations where one's physical integrity is not immediately at stake. It seems that as society we are both fascinated and frightened by the role emotions play in our behaviour, and in our everyday moral perceptions and motivations.

When positive moral emotions are considered (the emotions which encourage cooperative and socially constructive behaviour), the extent to which they are likely to emerge largely depends on how familiar we are with others. Generally speaking, the more one knows about the circumstances and identity of another person, the more likely it is that one will be able to empathize with and act benevolently towards that person. On a general level, we need rationalistic ethics to regulate our morally relevant behaviour towards the others who are not close to us. However, the practicalities of how easily or effectively such rationalistic ethics will actually 'work' often depends on our ability to imagine that we know the people whom we do not know, or to envision parallels between them and the people whom we actually know. In everyday moral discussions it is thus common that we remind others to govern their actions as though they knew the (unfamiliar) people to whom they need to relate. When someone acts recklessly to another, they will often be cautioned by their close peers by saying something of the sort: 'imagine that this is your sister (or mother, or brother), how would you feel if somebody treated them that way', or 'how would you like it if your friends acted towards you the way you acted towards him/ her'. We use the same kind of parallels when we morally educate our children. Whenever the actual motivation to act morally is considered concretely, references tend to be made to or parallels drawn with one's familiar and close relationships. The reason for this is that moral action ultimately rests on moral emotions which are the most effectively exercised in 'organic', immediate and intimate relationships with our close ones, rather than in detached, formal and institutionally mediated relationships with those distant from us.

The more one's character traits, life circumstances and a particular predicament are known to us, the more information we have to empathize with the person. Without empathy, any decision to take a sacrifice, ranging from giving a token amount to charity to donating a kidney, may be difficult to take. The question of empathy, thus, remains central to our discussion of morality.

\section{Empathy as an understanding of others}

One of the key aspects of empathy is the ability of the empathizing person to distinguish between their own and the feelings of others, with whom they empathize, while at the same time showing an emotional reaction to the discomfort or suffering that others are undergoing. Thus, empathy requires a degree of maturity in understanding our own feelings and those of others. It differs from merely 'taking on' the feelings of others, or succumbing to what is sometimes called 'emotional infection'. In mass psychology it is well known that strong leaders' personalities are able to induce feelings to the mass of followers: people who gather at rallies often start to feel the emotions that emanate from the speakers. They believe that the revolt, enthusiasm or revolutionary drive are their own, while in fact they are merely 'caught' from those who infect the entire group with their own emotions, ambitions and resentments. While most people are susceptible, to some degree, to emotional infection, empathy is only possible where there is no emotional infection. Feeling the emotions of others automatically rules out the possibility of empathy. Thus, empathy is a more independent reaction to the suffering of others than the taking over of their emotions. It recognizes others as distinct individuals and posits certain commonalities between ourselves and them which make it easy for us to feel for them in their pain (not to 'share in' their pain, 
though the two are frequently confused). This interpretation, which was initially developed by Max Scheler, is far more discriminating than the Humean interpretation of empathy as 'emotional contagion'. While Hume sees empathy as another's emotion that invades the observer, Scheler makes it very clear that emotional infection and identification with another occur throughout the natural world, among a variety of animals, with no empathy involved. He discusses our capacity for emotional contagion as biological rather than psychological or moral. He thus insists on distinctions between the categories of emotional identification, emotional infection, sympathy (or 'fellow-feeling'), which is closest to empathy, and a variety of other ways to relate to one another's emotions [9]. Even Michael Slote, a key modern sentimentalist ethicist, appears to miss Scheler's distinction when he insists on the normative ethical capacity of the Humean understanding of empathy as contagion. He realizes that there is something important in the distinction between emotional contagion, or taking over of another's feelings, and feeling for others because they are undergoing suffering with which we can cognitively identify and which we feel we 'understand', though we are aware that it is not our emotion. However, rather than making it clear that such a distinct identity is a requirement for exercising proper empathy, Slote ascribes a conceptual confusion to Hume: he says that Hume erroneously used the concept of 'sympathy' to refer both to empathy and what 'we could consider' sympathy today [11]. Slote devises a sentimentalist ethics by resorting to the concept of 'moral goodness' which is explained in terms of caring for others: thus, any action that is motivated by caring for others and empathizing with them is morally good and conversely, actions which arise from a disregard of the well-being of others are morally bad. While I do not wish to criticize Slote here at any length (in fact I agree with most of his general argument in lieu of sentimentalism), I do wish to point to the conceptual juncture where he misses Scheler, because I think this is a key juncture which tells us a lot about the normative potential of relational emotions and their cognitive role.

Relational emotions arise with regard to the emotions of others which we understand and relate to. Substantive emotions, on the other hand, are our own authentic emotions. It is interesting that one might hold mutually opposed substantive and relational emotions at the same time, such as feeling anxious about an upcoming medical intervention (substantive emotion), and at the same time happy for one's neighbour who sings in front of an open window because he has fallen in love. Relational emotions are somewhat similar to, but not to be confused with, meta-emotions. The latter are felt with regard to other, primary emotions of the same person: I might feel ashamed of my own fear, depressed about my feeling of guilt, or angry at my own malignant rejoicing at the misfortune of my sporting competitor who cannot challenge me at a contest. Similar considerations apply to moral emotions which determine the modal logic of our decision-making. For example, in integrative psychotherapy, both the emotions involved in certain actions and the meta-emotions involved in the subsequent judgement and appraisal of those emotions play a role in our ability to move between the various modal worlds, or sets of relevant circumstances, from which we may have different vistas on life and on the specific choices we make [2]. Meta-emotions are relevant for ethics because they arise from internalized values, including moral values; however, they are not the same as relational emotions; the latter are felt in relation to the emotions of others which we understand and with which we are able to imaginatively identify. Relational emotions create a conceptual space for the positing of moral obligation to others while meta-emotions, which relate to one's own self, do not. Because Slote does not see empathy as rooted in an awareness that the feelings of others that we empathize with are not our feelings (in fact he suggests that in empathy others' feelings become ours) he fails to conceptualize a sentimentalist ethics in terms of the moral obligation between different persons. He rather resorts to the relatively fuzzy concept of 'moral goodness' which is based on altruism and empathy, and falls short of establishing a moral obligation to act in certain rather than other ways. The problem is logical: if empathy is the basis on which moral goodness is decided, and empathy fuses the identities of the sufferer and the observer by requiring the observer to be invaded by another's feelings, then the awareness of distinct identities and situations of the sufferer and observer is considerably blurred. This alone makes it difficult to clearly posit a moral obligation between two actors whose distinct individualities are not entirely clear to them. The more dramatic the feeling, the less clear the awareness of the distinctness in emotions and perceptions between the two is likely to be.

Scheler, on the other hand, goes to the other extreme by insisting that any kind of emotional reaching out between the observer and the sufferer undermines the possibility of moral obligation and consequently, ethics. This is why he is adamant, seemingly quite counterintuitively, that however suggestive his ethics, 
no ethics of sympathy is possible in principle: sympathy does not allow for a proper conceptualization of duty [9, p. 38].

In order to understand the moral obligation a clear distance must exist between the identity of the moral actor and that of another person towards whom there is a moral obligation. Any fusion of identities between the subject and object of moral obligation cuts this distance short. While in such a situation some 'moraly good' things can be done, no clear moral duty is possible. Although he wants to explain emotions in largely biological terms and classify them comprehensively as natural phenomena, Scheler is essentially a German tradition dutyethicist, and is thus reluctant to allow any room for proper ethics in his account of sympathy, though he is undoubtedly aware of the social dimensions of all of the 'fellow-feeling'-related phenomena which he discusses.

In his generally Humean context of sentimentalism, Slote argues that any type of altruism as morally desirable behaviour involves the capacity for empathy, and claims that this is so a priori 'for anyone with a developed sense of empathy': '< ..> it is a priori, I think, that morality depends on altruism, and I shall be arguing that anyone well-acquainted with empathy in their own case and that of others can also see a priori that altruism and morality involve empathy (among other things) [11, p. 18]. While I agree with Slote's direction of argument that empathy is crucial to morality conceived in terms of altruism, and that developing people's morality involves systematically developing their capacity for empathy, I do think that his argument is imprecise because it does not pay sufficient attention to relevant distinctions between the ideas of moral obligation and an overly generalized view of 'moral goodness' that he uses. In fact, it is not entirely clear what Slote means by moral goodness other than that it is generally morally desirable to act altruistically. He does not seem to be content with a type of preference-ethics which in the normative sense falls short of establishing a moral obligation: he argues that sentimentalism could in fact be construed as the last defence of deontology [11, p. 98]. At the same time, however, he does not show how an ethics based on 'natural motives' can really found a deontological moral normativity rather than limiting itself to generally pointing to morally praiseworthy directions of action [11, p. 106].

It seems to me that Hume's treatment of sympathy and empathy as close, almost synonymous concepts are based on good reasons. I am not at all sure that today 'we understand' sympathy and empathy as such different con- cepts as Slote suggests. He insists that empathy is feeling another's emotions rather than 'feeling for' others [11, p. 15]. He considers the former 'empathy' and the latter 'sympathy'. This is a crucial misconception which both Hume and Scheler have good reasons to give wide berth to in developing their arguments. Although Scheler conceives of empathy sharply differently from Hume (in terms of the awareness of a difference in feelings between the observer and the sufferer), neither treats empathy and sympathy as clearly distinct concepts. They merely conceive them differently in terms of what empathy/sympathy means, however both see them, by my lights correctly, as close, almost synonymous notions. Once we understand that empathy (as well as sympathy) is a relational emotion with regard to the emotions we know others feel, we are able to posit a moral obligation and moral duty towards another which arise from our understanding of what others feel and our awareness that 'moral goodness' (which we can then freely understand as moral duty or obligation) requires us to try to remedy another's situation if we can.

If I feel the grief of a mother who has lost her child in a terrorist bombing, I am crushed by the feeling; I am both incapacitated to act and unaware of my own feelings which are pushed into the background. There is no room for perceiving a moral obligation towards the mother. However, if I empathize with the mother while being fully aware that the grief is hers, not mine, I am able to understand a moral duty to help her survive the grief: I am then able to try to comfort her, move her to a safe place, help her deal with the funeral, the social and existential aspects of the event. I am only able to be a moral actor in terms of moral obligation or duty if my identity and my feelings are clearly separate from hers. Whether this is called empathy or sympathy is not all that relevant, and this is likely the reason neither Hume nor Scheler made any effort to distinguish between the two.

The above is the same distinction that Martin Hoffman makes when he discusses the emotional and cognitive development of children, who first react to the distress of others (crying) by possibly confusing it with their own distress (once one baby in a room with babies starts to cry, many other babies will automatically cry as well), but as they grow up they learn that the distress of other children is not their own distress, while still showing what Hoffman calls 'empathic disturbance' by the distress of others. Like Scheler, Hoffman makes it very clear that a developed empathy involves a clear awareness of one's identity as 
distinct from that of the person empathized with. He sees emotional development largely in terms of acquiring a capacity for empathy as an emotional reaching out to others without violating the boundary between one's own and another's feelings by emotional contagion [5].

The key difference between empathy and emotional contagion is in the responsibility that remains with the person who empathizes with others, while it disappears when one becomes emotionally infected by another. Being invaded by feelings of the grieving mother partially relieves me of a responsibility to relate to her pain in an active, altruistic way. I might or might not be able to assist her; what emotional infection does necessarily involve is my 'plugging into' her pain: any moral action which might ensue is merely contingent. Empathy, on the other hand, keeps me in the position of responsibility for another: I remain aware that her feelings are crushing for her, and I am able to impose on myself a sense of moral duty or obligation to do something altruistic for her. It is this active element of altruism that requires a sense of responsibility; this sense, in turn, requires a clear delineation of my feelings from hers. The normative moral question here is: should I feel empathy for others and act accordingly (this will automatically make me an altruistic person)? If I should, then I must understand others sufficiently, I must know enough about them and the way they perceive their experiences. I must see them as similar to myself sufficiently to understand them, while at the same time keeping them at a sufficient distance in terms of their identity to be able to sense a moral obligation to them as distinct personalities with experiences and circumstances which are different from mine.

The formulation of the normative statement that I should be empathetic and altruistic leads me to the question where I can happily agree with Slote's general argument, namely the question of whether and how we can enhance empathy. One obvious way to do so is to establish the pre-requisites for learning empathy.

\section{Learning empathy: Why emotions are not 'irrational'}

The feature of empathy that it is opposed to emotional infection is key to understanding the rational aspect of empathy: like most emotions, contrary to general belief, empathy is not entirely 'irrational'. Specific emotions have their own logic and their own particular relationship with values; they help us to understand when a value that is important to us is at stake. Thus, emotions help identify important value-aspects of one's own identity and generate impetus to act to address any issues with such values. One might not always rationally know that some values are important to them; one might not always rationally understand key aspects of who one really is. Where one might rationally think that certain values are more or less important to them than they really are, the emotional responses (especially the negative emotions when such values are threatened) help correct the perception. Thus, emotions are crucial cognitive avenues to a better understanding of our own identity. Hence, therapeutic approaches which see intense, disturbing emotions as a problem and strive to place them under control by the use of pharmaceuticals may actually make it more difficult for the person to understand their identity sufficiently to effectively deal with outstanding issues in one's life. Emotion's 'tag' or mark the most important values whether we are aware of them or not: in order for an experience to trigger an emotion, a high-ranking value in the person's value-system must be either affirmed (pleasurable emotions) or deterred (displeasing emotions). Such emotions, as dynamic factors, allow us to 'switch' between the different modal worlds in making our everyday decisions. Thus pleasing or displeasing emotions are the core factors of our psychodynamics [1].

This cognitive aspect of emotions is particularly relevant for ethics when empathy is considered. Empathy is possible only where one is able to sufficiently understand the life and plight of others; thus, the more emotionally and cognitively transparent communities are, the more likely it is that people will empathize with one another. While empathy has undeniable dynamic qualities in that it can motivate action in solidarity with others and can generally strengthen motivation for all kinds of collective action, its cognitive value is often under-appreciated [3].

Unlike substantive emotions, which carry their own psychic energy arising from their immediate presence in our mind and their ability to colour our perception, even a sense of ourselves, thus needing no particular knowledge other than the immediate awareness of the emotion as our own, relational emotions require a prior cognitive understanding of a situation which is different from our own emotional state. This is why substantive emotions cannot be a proper foundation for ethics, while relational emotions can.

The rational extension of this insight is in the issue of how moral sentiments, specifically empathy, can be developed culturally, how they can be ingrained more effectively, or how 
people can be socialised into such sentiments, or taught to feel them more strongly and more often [8]. This is what developmental psychology studies as moral development, which is directly linked to the learning of emotions. The very process of emotional learning rules out any idea that emotions are irrational and contradictory to reason - the idea that so much traditional philosophy has taken for granted through the division of 'faculties', perhaps due to the influence of the Carthesian tradition on the western thought. Descartes' cogito can be viewed as a Husserlian 'phenomenological reduction' of the attributes and appearances of existence, or self-existence, to a basic, irrefutable truth of me thinking, thus, necessarily, existing, without having to consider anything else to prove the fact of existence. However, it is also a celebration of thought and rationality, and this latter meaning of it has caused the largest part of the western philosophical tradition to assume that the 'I think', or more precisely, 'I reason', is somehow fundamentally different from, and superior to, the 'I feel' of everyday life.

While the sense of emotional relationship to everyday life experiences may be viewed in primarily ethical terms, namely as contributing to, or detracting from, the quality of life, it also plays an important epistemic role. Our moral emotions make us aware of the ecology of values within which it only becomes possible for us to articulate our identities. To understand who I am, I first must position myself within a normative framework of values, and to assess my own individuality I must be able to relate it to certain conceptions of ideal virtue, or sin, of solidarity, empathy, and other important values which define the moral ideal of my community. Even if these ideals are the so-called negative values, characteristic of what some call "the post-heroic age", such as tolerance, restraint or resilience (the virtues which emerge only when affirmative values are denied, or militated against by our current circumstances), we are able to learn about our identities based on the moral emotions that we experience against the bedrock of such defining values for our community. When we speak of the political right, or the political left, our discourse is often imprecise and for external observes, who are not immediate participants in the discourse, it may seem arbitrary. The reason is that when people discuss ideology, they primarily address their relational moral emotions about values such as justice, equality, rule of law, individual dignity, solidarity, etc. Such emotions do not conform to strict conceptual divides, but nevertheless they serve an important epistemic role, and this is reflected in the fact that, although we may not be able to clearly define what this means, we are generally well aware of what ideals typically stand for what ideologies. Equality seems to be a prodigious feature of the value ecosystem of the leftist ideology, not because the so-called right ideologies do not recognise the importance of equality, but because those who associate themselves with the left ideologies tend to argue passionately for equality. Similarly, the right ideology appears to be automatically associated with values such as individual liberty and market competition, not because some other ideology does not take those values onboard as well, but because the investment of moral emotionality, of what Robert Solomon calls "passion" for values in the public discourse of a particular ideology is particularly strong with regard to those particular values. The way we feel about moral values and the way we express these emotions teaches both ourselves and others about where we stand on the social spectrum of beliefs, or in the general ecology of values of our society.

The Covid 19 pandemic of 2020 and 2021 (to continue for an unknown period, as it appears at the time of writing of this article) has challenged communities in several important ways which highlight the need to rely on our individual and group ecologies of moral emotions and values which these emotions point to. The virus has torn down numerous social practices (including the sociality itself, in its immediate aspect, not facilitated by electronic communications and not dampened by social and physical distancing). As a result, the pandemic has cancelled many physical, procedural and institutional ways for us to orient ourselves in new and challenging situations. The new reality exhibits itself not only in most of the western world's civilisation staying at home for protracted periods of time, being subjected to curfews and lockdowns, and moving to working from home, but also in more emotionally changed existential and border experiences, such as dying alone, without friends and family, in isolated hospital wards surrounded by staff in scafanders whose faces one cannot see. Families now face situations where they cannot say goodbye to their loved ones who have deceased from the Coronavirus, and instead they attend funerals where they only see a sealed coffin and must maintain a distance between the few others allowed at the funeral, all of whom wear masks. This is a profound change to how we had been used to experience not only life, work and play, but also death.

In the changed circumstances, such as the ones induced by the current pandemic, values 
are tested, especially the moral and social values, which are relational by nature and by structure. It seems that in such circumstances we are deprived of everything other than the moral values and the emotions we can express based on these values to show who we are in testing life situations. Thus, the intellectual cultivation of our values and the emotional articulation of our perceptions of and reactions to these values are all the more important. It appears that the epistemology of values, or more precisely the epistemic interpretation and articulation of both our individual ecologies of values and moral emotions as their affective counterparts are among the few remaining beacons of identity that are left to us when social practices, institutions and procedures are threatened. Thus, it appears that philosophy is the last defence against civilisational demise illustrated by global crises, such as the one associated with the global meltdown of established social practices induced by the current Covid 19 crisis.

Acknowledgments: This article has been completed with the support of the Ministry of Education, Science and Technological Development of the Republic of Serbia.

\section{References}

1. Fatić A. (2019) Romanian Journal of Philosophy (Revue Romaine de Philosophie), no. 63 (2), pp. 351364 [in Eng].

2. Fatić A. (2020) Synthesis Philosophica, no. 35 (2), pp. 289-293 [in Eng].

3. Fatić A., Zagorac I. (2016) Philosophia, no. 44 (4), pp. 1419-1438 [in Eng].

4. Freedland J. (2016) The Guardian, no. 15, January [in Eng].

5. Hoffmann M.L. (2000). Empathy and Moral Development. Cambridge, Cambridge University Press [in Eng].

6. Islamic State like Nazism, Italian philosopher Umberto Eco says (2015). Japan Times, 9 January [in Eng].

7. Miller R. (2011) Facing Violence: Preparing for the Unexpected. Wolfeboro,YMAA Publication Center [in Eng].

8. Nussbaum M.C. (2013) Political emotions: Why love matters for justice Harvard, Belknap Press [in Eng].

9. Scheler M. (1954) The nature of sympathy. Translated by Peter Heath. London, Routledge and Kegal Paul [in Eng].

10. Scherer K. (2009). Cognition and Emotion, no. 27 (7), pp. 1307-1351 [in Eng].

11. Slote M. (2010). Moral sentimentalism. Oxford, Oxford University Press, pp. 25-30 [in Eng].

12. Up to 3 million copies of new Charlie Hebdo edition to carry cartoon of Prophet Mohammad (2015). The Independent, 13 January [in Eng].
Для цитирования: Фатич А.

Ценность идентичностей:

личность как экология ценностей //

Социум и власть. 2021. № 2 (88). С. 18-25.

DOI 10.22394/1996-0522-2021-2-18-25.

DOI 10.22394/1996-0522-2021-2-18-25

УДК $17.03+177.1$

\section{ЦЕННОСТЬ ИДЕНТИЧНОСТЕЙ: ЛИЧНОСТЬ КАК ЭКОЛОГИЯ ЦЕННОСТЕЙ}

Фатич Александр (Fatić Aleksandar),

доктор философии, профессор,

Институт философии и социальной теории, Белградский университет (Сербия).

45 Kraljice Natalije Street, 11000 Belgrade, Serbia. E-mail: fatic@instifdf.bg.ac.rs

\section{Аннотация}

В статье исследуется концепция ценности индивидуальной и коллективной идентичностей, основанная на понимании ценностей с позиции эмоций. Основная точка зрения, представленная в статье, заключается в том, что эмоции являются наиболее важным практическим инструментом для прояснения индивидуальных и коллективных ценностей. Аргументируется, что моральные эмоции не являются чем-то иррациональным, напротив, они имеют собственную логику, которая может точно охарактеризовать систему ценностей человека. Таким образом, эмоции являются важнейшими строительными блоками этики, способной укрепить личную и моральную идентичность. Эта особая экология моральных эмоций имеет решающее значение в периоды кризиса, такие как глобальные пандемии, войны или системные сбои, будь то экономические или политические, связанные с вопросами безопасности, дипломатические или культурные. В нынешних обстоятельствах, когда уже пошатнувшиеся индивидуальные и коллективные ценности во всем мире были еще более расшатаны пандемией Covid-19, понимание идентичности, находящей фундаментальное выражение в моральных эмоциях, может иметь решающее значение для спасения нашей культуры и ее социального и морального капитала.

Ключевые понятия:

ценности,

идентичность,

моральные эмоции,

эмпатия,

социальный / моральный капитал. 